RESENHAS 


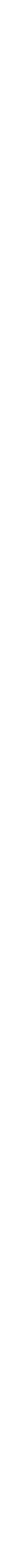




\section{JÚDICE, Nuno. A matéria do poema. Lisboa: Dom Quixote, 2008. $132 \mathrm{p}$.}

Silvana Maria Pessoa de Oliveira Universidade Federal de Minas Gerais momento, 29 livros de poesia. Pode-se dizer que na sua obra poética destacam-se certos procedimentos e técnicas de composição que a distinguem no amplo e diversificado contexto da poesia atualmente dada à estampa em Portugal. Um desses procedimentos é o da variação, aqui utilizado no sentido que lhe confere a música e que consiste em modificar uma melodia em seus aspectos secundários, sem, contudo, desfigurar o tema original. No caso de Nuno Júdice, a variação pode ser entendida como um procedimento poético que ganha forma em parte considerável de seus livros de poesia. Isto quer dizer que há determinados eixos temáticos, imagéticos e metafóricos que se repetem - sempre em diferença - de livro a livro, constituindo algo como uma série que potencialmente pode se estender ao infinito.

Desde o primeiro livro publicado, A noção do poema, de 1972, certas seqüências temáticas, formais e metafóricas vêm se expandindo, à maneira de círculos concêntricos, o que permite, ao leitor, elaborar uma espécie de "geometria variável", ocupada por questões e imagens que, recorrentemente, se vão desenvolvendo em direção a uma, digamos, poética da 
variação. Com efeito, é notável o modo como os livros de poesia de Nuno Júdice organizam-se, com freqüência, em torno de motivos e situações como as denominadas "cenas de escrita" conforme observa muito apropriadamente Rosa Maria Martelo - e as "cenas de leitura", estas conduzidas pelos poetas que compõem o cânone particular do sujeito poético, tais como Luis de Camões, Fernando Pessoa ou Cesário Verde, para ficarmos apenas com os portugueses.

Por seu turno, a utilização de elementos e figuras tomadas de empréstimo à tradição greco-latina, com especial recorrência a Ulisses, o Minotauro, o labirinto, a Esfinge, Circe, dentre outras de igual relevância, atesta a natureza de um projeto poético que assume como sua a tarefa de reler, reorganizar e ressignificar o chamado "legado dos outros". Sabe-se o quanto é comum, na Modernidade, a poesia dramatizar modos de convívio com a tradição literária; neste cenário, o poeta está, antes de mais, comprometido com a tarefa de reconfiguração dos mitos, sejam eles coletivos ou não. Como organizador do "legado dos outros", é também um leitor privilegiado, capaz de rever e reestruturar os textos, colocando-os em diálogo com o tempo presente e a própria poesia.

Neste sentido, em A matéria do poema, Nuno Júdice comenta, retoma, "organiza" poetas e escritores como os já citados Luis de Camões, Fernando Pessoa e Cesário Verde, além de David Mourão-Fereira, D.H. Lawrence, José Saramago, entre outros, empenhando-se em criar variações, a partir da releitura crítica da obra deles, que sejam capazes de expor, sempre de forma reflexiva, a partilha de presenças e de vozes que constituem, em última instância, a "matéria do poema". Peças deste livro como "A mala do poeta" e "Cesário Verde (variante sem burguesas)", entre inúmeras outras, constituem exercícios nos quais se utilizam aberta e livremente certos motivos poéticos tradicionais, não com o intuito de "restaurar" 
algo já feito, mas para recolocar em uso, trazer novamente à circulação modos diversos de fazer poesia. É o que corroboram os versos finais de "A mala do poeta", que podem muito apropriadamente ser lidos como uma "arte poética":

(...) O problema do Pessoa é que não viajava de arca atrás dele, porque se o fizesse teria de arrumar a arca, como se arrumam as malas. Odes no lugar das odes, sonetos com sonetos, e cada heterônimo no seu sítio, sem nada a tirar nem acrescentar. Mas ao contrário da mala do Campos, a arca do Pessoa ficou para que outros a arrumassem, e não têm faltado arrumadores porque a arca é grande, e cabem lá dentro muitas mãos. Eu é que não preciso de meter a mão na arca, porque basta-me aquela Edição com o cavalinho do Almada, e quantas vezes não montei Nele para correr à desfilada, sem sela nem treino, por esses campos Que o Campos abriu, de cada vez que se fechava a mala e partia Para outra, ou mesmo quando voltava, porque a mala é que não saía De ao pé dele. E ainda bem para nós, que não temos de escolher Entre a mala e a arca, nem temos de arrumar nada porque, nestas Coisas da poesia, a arte está na arrumação com que o poeta Desarruma tudo.

Certamente, diversas outras "séries" e "seqüências" judicianas poderão ser exploradas neste A matéria do poema. Há, a título de exemplo, um grupo relevante de composições que tratam da memória da infância, das reflexões sobre a passagem do tempo e a conseqüente consciência da perecibilidade de seres e coisas sujeitos a seu regime, das meditações acerca da natureza do amor e do desejo. Vistos em seu conjunto, nestes 96 poemas que integram o volume em pauta, Nuno Júdice expande e fortalece seu aparato poético-crítico de leitura, num movimento complexo, contínuo e dinâmico que está longe de dar mostras de esgotamento. 


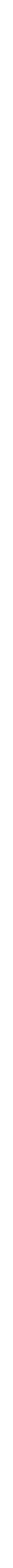

